University of Nebraska - Lincoln

DigitalCommons@University of Nebraska - Lincoln

Papers in Biotechnology

Chemical and Biomolecular Engineering

Research and Publications

July 1999

\title{
Bioactivities of a tumour necrosis like factor released by chicken macrophages
}

Silke Rautenschlein

University of Minnesota

Anuradha Subramanian

Department of chemical Engineering,University of Nebraska Lincoln., asubramanian2@unl.edu

Jagdev M. Sharma

University of Minnesota

Follow this and additional works at: https://digitalcommons.unl.edu/chemeng_biotechnology

Part of the Biochemical and Biomolecular Engineering Commons

Rautenschlein, Silke; Subramanian, Anuradha; and Sharma, Jagdev M., "Bioactivities of a tumour necrosis like factor released by chicken macrophages" (1999). Papers in Biotechnology. 41.

https://digitalcommons.unl.edu/chemeng_biotechnology/41

This Article is brought to you for free and open access by the Chemical and Biomolecular Engineering Research and Publications at DigitalCommons@University of Nebraska - Lincoln. It has been accepted for inclusion in Papers in Biotechnology by an authorized administrator of DigitalCommons@University of Nebraska - Lincoln. 


\section{Introduction}

Tumour necrosis factor (TNF)- $\alpha$ is a major monocyte/macrophage derived cytokine that can also be produced by many other cell types including lymphocytes, neutrophils. and astrocytes. It is produced in response to invasive stimuli such as bacterial, viral, fungal, parasitic or neoplastic agents. TNF-a induces many gene products involved in inflammation, tissue repair, hematopoesis. immune response, and anti-tumour effects [1]. TNF genes have been cloned in numerous mammalian species [2-10] but attempts to clone chicken TNF have been unsuccessful so far.

The mature form of mammalian TNF- $x$ is a trimer of identical $17 \mathrm{kDa}$ subunits each derived from a $26 \mathrm{kDa}$ initial translation product [11]. TNF induces the production of other gene products such as cytokines and their receptors, adhesion molecules, and class I and II MHC molecules [12-15]. TNF has been reported to synergise with other cytokines, especially with IFN- $\gamma$ to induce or compound IFN effects [16].

Information about TNF in chickens is limited. Cytotoxic TNF-like activity was shown to be induced by Eimeria infection or lipopolysaccharide (LPS) stimulation of chicken macrophage populations [17-20]. TNF-like activity was detected by cytotoxic activity assays performed with mouse $[17,18]$ or chicken fibroblast cell lines $[19,20]$. Western blotting using anti-human and anti-mouse TNF- $\alpha$ antibodies demonstrated that TNF was expressed during early chick development [21]. However, it is neither known if this factor is the avian homologue of mammalian TNF, nor has this factor been biologically characterised further.

Our objective in this study was to identify an avian TNF-like factor in chicken macrophage cell supernatants and characterise its biological activities in vitro. The production of TNF-like factor was induced by LPS in the chicken macrophage cell line MQ-NCSU [22] and further characterised by ion-exchange and gel permeation chromatography (GPC). Each fraction of MQNCSU conditioned medium was tested for the following TNF-like characteristics: cytotoxicity; up-regulation of Ia-expression; NO induction; and synergism with IFN- $\gamma$. The cross-reactivity of anti-mammalian TNF antiserum with chicken TNF-like factor was determined, which may give an indication for structural homology between mammalian and chicken TNF.

\section{Materials and methods}

\section{J. Materials}

Mouse anti-chicken Ia-FITC was purchased from Southern Biotechnology Associates, Inc. (Birmingham, AL); Leibovitz's L-15 medium, McCoy's 5A medium, RPMI 1640, Dulbecco's modified Eagles medium (DMEM), Penicillinstreptomycin sulfate and L-glutamme were obtained from Sigma (St Louis, MO) as well as LPS, G-75 Sephadex beads, MTT (3-(5,5dimethylthiazol-2-yl)-2,5-diphenyl-tetrazolium bromide and the horseradish peroxidase (HRP) conjugated goat anti-rabbit IgG. Recombinant human TNF- $\alpha$ and rabbit anti-human TNF-a antiserum were obtained from Genzyme Diagnostics (Cambridge, MA): dialysis bags Spectra/Por", 12-14 kDa cut off, were purchased from Spectrum Medical Industries (Houston, TX); DEAE Sepharose ${ }^{n}$ Fast Flow was purchased from Pharmacia Biotech Products (Piscataway, NJ). Phosphate-buffered saline (PBS) was obtained from Celox Laboratory, Inc. (St Paul, MN); BioBlot-NC ${ }^{\text {, }}$, Nitrocellulose blotting membrane from Costar (Cambridge, MA); ImmunoPure ${ }^{B}$ metal enhanced DAB substrate kit from Pierce Chemical Co. (Rockford, IL); the $10-20 \%$ gradient SDS polyacrylamide pre-cast gel, the Mini-protean "II cell and Tween-20 from Bio-Rad (Hercules, CA); and the SeeBlue Prestained standard was purchased from Novex (San Diego, CA).

\subsection{Induction of TNF-like activity}

To induce TNF-like activity, the chicken macrophage cell line MQ-NCSU [22] was seeded at a cell density of $5 \times 10^{5}$ cells $/ \mathrm{ml}$ and grown overnight in Leibovitz-McCoy's (1:2) complete medium containing tryptose phosphate broth 
$(5 \%)$. fetal calf serum (FCS; $5 \%)$, chicken serum $(5 \%)$, L-glutamine $(200 \mathrm{mM} / \mathrm{ml})$, penicillin $(50 \mathrm{U} /$ $\mathrm{ml})$, and streptomycin $(50 \mu \mathrm{g} / \mathrm{ml})$. The medium was replaced by incomplete medium without sera and supplemented with $10 \mu \mathrm{g} / \mathrm{ml}$ LPS. The cells were then stimulated for $16 \mathrm{~h}$, and the supernatant was harvested. The supernatant was clarified by centrifugation at $4000 \times \mathrm{g}$ and used for further purification or stored at $-80^{\circ} \mathrm{C}$.

\subsection{Chromatography of TNF-like factor activity}

To enrich TNF-like factor activity, onc litre of conditioned media was dialysed overnight at $4^{\circ} \mathrm{C}$ against deionised (DI) water using dialysis bags with a molecular weight cut-off of $12-14 \mathrm{kDa}$. The dialysed supernatant was concentrated by lyophilisation. The dry lyophilisate was dissolved in $130 \mathrm{ml}$ of buffer 1 (25 mM Tris-base, $50 \mathrm{mM}$ $\mathrm{NaCl}, \mathrm{pH} 7.2$ ) and stored at $-90^{\circ} \mathrm{C}$ until further use. Chromatographical separation of the dissolved lyophilisate was performed on a $1 \times 10 \mathrm{~cm}$ column of DEAE Sepharose "Fast Flow (FF) at a volumetric flow ratc of $1 \mathrm{ml} / \mathrm{min}$. Ten to twenty column volumes (CV) of buffer 1 were utilised to equilibrate the DEAE FF column prior to each run. Forty to eighty millilitres of sample of the reconstituted lyophilisate were loaded to the equilibrated DEAE FF column at a flow rate of $1 \mathrm{ml} / \mathrm{min}$, and the column flow through (FT) was collected. Upon completion of the sample-loading step, the column was washed with $20 \mathrm{CV}$ of buffer 1 until the baseline ABS $280 \mathrm{~nm}$ was achieved. The bound proteins were rluted with $10-15 \mathrm{CV}$ of buffer containing $0.4 \mathrm{M}$ and $1.0 \mathrm{M} \mathrm{NaCl}, \mathrm{pH} 7.2$.

The FT and the eluates were monitored for protein content at $280 \mathrm{~nm}$ absorbency and for TNF activity in the cytotoxicity assay. All chromatographic separations were carried out at $4^{\circ} \mathrm{C}$.

The TNF-active fraction from the DEAF-step was concentrated by lyophilisation. The concentrate was then dissolved in $3 \mathrm{ml}$ of column buffer (buffer 2; $20 \mathrm{mM} \mathrm{Na} \mathrm{HPO}_{4}, \mathrm{pH}$ 7.0). Sephadex G-75 beads were swollen in buffer 2 according to manufacturer's instructions. Hundred millilitres of column buffer were run through by gravity $(! \times g)$ to accomplish packing of the column
$(1.5 \times 30 \mathrm{~cm})$. Non-specific binding sites on the resin beads were blocked by including $2 \mathrm{mg} / \mathrm{ml}$ bovine serum albumin in buffer 2 during the packing process. A pump and fraction collector were attached to the column and calibrated. Four pools were collected in each of three runs with identical profiles. The peak pools were frozen, lyophilised and resuspended in $15 \mathrm{ml}$ water and dialysed for $4 \mathrm{~h}$ at $4^{\circ} \mathrm{C}$. The dialysed pools were frozen, relyophilised dry and stored at $-80^{\circ} \mathrm{C}$. After resuspension in PBS, the samples were monitored for protein absorbency at $280 \mathrm{~nm}$ and analysed for TNF activity and for crossreaction with anti-human TNF- $x$ antibodies in Western blotting procedures.

\subsection{Assay for TNF activity}

For the assessment of chicken TNF activity, the chicken fibroblast cell line CHCC OU-2 [23] was used in a cytotoxicity assay as the target cell population following previously published procedures $[19,24]$. Briefly, CHCC OU2 cells were seeded into 96 well plates at $2 \times 10^{4}$ cells/well. After overnight incubation of the cells at $41^{\circ} \mathrm{C}$, serial diluted samples $(100 \mu \mathrm{l})$ were added in triplicates to each well. The diluted samples were incubated at $41^{\circ} \mathrm{C}$. After $48 \mathrm{~h}$, the plates were spun at $500 \times \mathrm{g}$ for $10 \mathrm{~min}$. Twenty five microlitres of PBS containing $2.5 \mathrm{mg} / \mathrm{ml} \mathrm{MTT}$ were added to each well after one washing step with PBS. Then the cells were lysed after $2 \mathrm{~h}$ of incubation at $41{ }^{\circ} \mathrm{C}$ with $20 \%$ SDS in $50 \%$ dimethylformamide, $\mathrm{pH} 4.7$, for $1.5 \mathrm{~h}$ at room temperature (RT). Measurement of the optical density (OD) of each well was conducted on an automated ELISA reader (Molecular Devices, Menlo Park, CA) at $570 \mathrm{~nm}$. All experimental samples were assayed at least three times and the results combined for data analysis. The specific cytotoxicity was expressed by the following formula: percentage cytotoxicity $=(A-B)$ / $(A-C) \times 100$ where $A$ represents the $O D$ value of control wells containing DMEM alone, $B$ represents the OD of the sample wells, and $\mathrm{C}$ represents the absorbency of wells to which $0.5 \%$ TritonX100 was added to achieve maximum cy- 
tolysis [20]. One unit of TNF is defined as the amount required for $50 \%$ cell lysis.

In order to examine the heat stability of chicken TNF-like factor, the samples were incubated at $56^{\circ} \mathrm{C}$ for $30 \mathrm{~min}$ or $95^{\circ} \mathrm{C}$ for $10 \mathrm{~min}$; in this manner residual LPS-activity could also be excluded prior to the assay $[25,26]$. In order to examine the antigenic relationship of chicken TNF-like factor with mammalian TNF, the chicken TNF-like factor was neutralised with a polyclonal rabbit anti-human $\mathrm{TNF}-\mathrm{a}$ antiserum. The samples, in dilutions of 1:100 and 1:1000 were incubated with serial dilutions of the antiserum for $2 \mathrm{~h}$ at $37^{\circ} \mathrm{C}$. Residual TNF activity of the samples was determined in the cytotoxicity assay. The neutralisation activity of this antiserum was confirmed by using recombinant human (rh) TNF- $\alpha$ under similar condition. Previously published procedures [24] were utilised to test the biological activity of neutralised and non-neutralised rhTNF- $\alpha$ by using L929 cells.

\subsection{Bioassay for NO-inducing activity}

The NO-inducing activity of chicken TNF-like factor was assayed by using HD1l cells (generously provided by $\mathrm{Dr}$ H. S. Lillehoj, United States Department of Agriculture, Washington, $\mathrm{MD}$, USA) following previously published procedures [27]. Briefly, $100 \mu \mathrm{l}$ of serial dilutions of samples were added to $10^{5} \mathrm{HD} 11$ cells cultured in phenol-red-lacking RPMI 1640 medium supplemented with $2 \% \mathrm{FCS}$ and penicillin/steptomycin $(50 \mathrm{U} / \mathrm{ml}$ and $50 \mu \mathrm{g} / \mathrm{ml}$, respectively). After $48 \mathrm{~h}$ of incubation at $41^{\circ} \mathrm{C} .100 \mu \mathrm{l}$ of these supernatants were assayed for NO using Greiss reagent $[27,28]$. The results were expressed as $U /$ $\mathrm{ml}$, with $1 \mathrm{U}$ equalling the amount of supernatant required to stimulate $10^{5} \mathrm{HD} 11$ cells to produce a concentration of $10 \mu \mathrm{M}$ of nitrite [27].

In order to determine synergistic effects between chicken TNF-like factors and IFN-y, serial dilutions of Pool 1 or recombinant chicken IFN-y (32 U/well), either alone or combined in $100 \mu$ l volume of medium. were added to $10^{5}$ HD11 cells and incubated for $48 \mathrm{~h}$ at $41^{\circ} \mathrm{C}$. The recombinant chicken IFN- $\gamma$ was expressed by a recombinant fowlpox virus (FPV) vector in chicken embryo fibroblasts (CEFs) [29] and thr IFN-y-concentration $(\mathrm{U} / \mathrm{ml})$ was determined ir. the VSV-protection assay [30]. As a negative control, supernatant from CEFs infected with the parent FPV was included in the experiment. At the end of the incubation period, supernatants were assayed for NO levels by using Greiss reagent as described previously.

\subsection{Flow cytometric analysis of la-up-regulation}

Cell surface MHC class II antigen expression on MQ-NCSU cells was detected after stimulation with various fractions of chicken TNF-like factor using monoclonal antibodies (Ia) against chicken MHC class II (Ia) [31]. One million cells/ $\mathrm{ml}$ of adherent MQ-NCSU cells in medium were stimulated with serial dilutions of chicken TNFlike factor for $48 \mathrm{~h}$ at $41^{\circ} \mathrm{C}$. As a positive control, the cells were stimulated with $10 \mu \mathrm{g} / \mathrm{ml} \mathrm{LPS}$. The cells were scraped off the tissue culture plate, washed once with PBS supplemented with $2 \%$ FCS, and $10^{6}$ cells were incubated with mouse anti-chicken Ia-FITC $\left(0.5 \mu \mathrm{g} / 10^{6}\right.$ cells $)$ for $1 \mathrm{~h}$ on ice. The cells were washed three times in PBS and fixed with 4\% paraformaldehyde. A FACSCalibur (Becton Dickinson, San Jose, CA) was used to analyse ten thousand cells per sample (FL-I channel).

\subsection{SDS-polyacrylamide gel electrophoresis and (PAGE) western blotting}

The samples were diluted 1:10 in DI water followed by addition of the same volume of denaturing sample buffer $(0.125 \mathrm{M}$ Tris, $4 \%$ SDS, $20 \%$ Glycerol, $0.2 \mathrm{M}$ DTT, $0.02 \%$ bromophenol blue). The samples were heated to $95^{\circ} \mathrm{C}$ for $5 \mathrm{~min}$ and $20 \mathrm{pl}$ were loaded onto each lane of a 10 $20 \%$ SDS polyacrylamide gel and electrophoresed for $1.5 \mathrm{~h}$ at $100 \mathrm{~V}$.

At this point the proteins were transferred at $4^{\circ} \mathrm{C}$ from the gel to a nitrocellulose membrane overnight at $200 \mathrm{~mA}$ constant current using a Mini-protean" II cell. Nonspecific binding of immunoglobulin was blocked by treating the transfer membrane with PBS containing $0.5 \%$ nonfat milk for $4 \mathrm{~h}$ at RT. After three washing steps with PBS containing $0.05 \%$ Tween-20 (PBS-T) for $10 \mathrm{~min}$ each, the membranes were incubated overnight at $4{ }^{\circ} \mathrm{C}$ with rabbit-antihuman TNF- $\alpha$ (1:1000), or pre-immune rabbit serum $(1: 1000)$ in PBS-T. This was followed by three washings with PBS-T and $1 \mathrm{~h}$ incubation with HRP-labelled goat-anti-rabbit immunoglobulin $(1: 100)$ in PBS-T. After three washing steps with PBS-T for $10 \mathrm{~min}$ each, the blots were developed with ImmunoPure ${ }^{\text {" }}$ containing $\mathrm{DAB}$ for $5 \mathrm{~min}$. The molecular weight was estimated by using the molecular weight standards

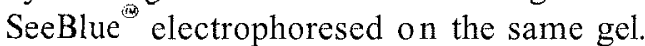


Table 1

Purification of chicken TNF-like factor from cell culture supernatant of LPS-stimulated MQ-NCSU cells

\begin{tabular}{|c|c|c|c|c|c|}
\hline Purification step & $\begin{array}{l}\text { Final volume } \\
\text { (ml) }\end{array}$ & $\begin{array}{l}\text { Total protein } \\
(\mathrm{mg})\end{array}$ & $\begin{array}{l}\text { Total cytotoxic activity } \\
\text { (U) }\end{array}$ & $\begin{array}{l}\text { Specific activity } \\
(\mathrm{U} / \mathrm{mg})\end{array}$ & Purification factor ${ }^{\text {at }}$ of TNF-like activity \\
\hline Starting material & 1000 & 2700 & $2 \times 10^{5}$ & $0.07 \times 10^{3}$ & \\
\hline $\begin{array}{l}\text { DEAE-Sepharose FT-fraction } \\
\text { G-75 Sephadex }\end{array}$ & 3 & 61 & $0.14 \times 10^{5}$ & $0.2 \times 10^{3}$ & 2.9 \\
\hline Pool 1 & 1 & 0.5 & $0.08 \times 10^{5}$ & $6.1 \times 10^{3}$ & 87.0 \\
\hline Pool2 & 1 & 5.1 & $0.03 \times 10^{5}$ & $0.6 \times 10^{3}$ & 8.5 \\
\hline Pool 3 & 0.5 & 2.6 & $0.02 \times 10^{3}$ & $0.58 \times 10^{3}$ & 8.2 \\
\hline Pool 4 & 1.5 & 6.6 & $0.018 \times 10^{3}$ & $0.27 \times 10^{3}$ & 3.8 \\
\hline
\end{tabular}

${ }^{a}$ Purification factor, specific activity of starting material/specific activity of the collected fractions.

\section{Results}

\subsection{Characterisation of the cytotoxic activity of chicken TNF-like factor}

The chicken macrophage cell line MQ-NCSU was cultured in serum-free medium for $16 \mathrm{~h}$ in the presence of $10 \mu \mathrm{g} / \mathrm{ml}$ LPS. Under these conditions, this cell line produced about $200 \mathrm{U}$ TNF-like activity per millilitre as estimated by the cytotoxicity assay. This amount is equivalent to a specific activity of $70 \mathrm{U} / \mathrm{mg}$ protein (Table 1). The FT fraction contained greater than $90 \%$ of the TNF activity in comparison to the fractions eluted at $0.4 \mathrm{M}$ and $1.0 \mathrm{M} \mathrm{NaCl}$, which contained $5-10 \%$ of the recovered activity (data not shown).

Fig. 1 shows a typical chromatography profile obtained from the fractionation of the pooled FT fractions on the G-75 GPC column. The pools represent in order, the void peak (Pool 1: $>81 \mathrm{kDa}$ ), a shoulder of the void peak (Pool 2: 70-55 kDa), a transition (Pool 3: 40-35 kDa) and a small included peak (Pool 4: $<25 \mathrm{kDa}$ ) (Fig. 1). Pool 1 had the highest specific TNF-like activity with $6.1 \times 10^{3} \mathrm{U} / \mathrm{mg}$ recovered protein; Pools 2, 3 and 4 had cytotoxic activities of $0.6 \times 10^{3} \mathrm{U} / \mathrm{mg}, 0.58 \times 10^{3} \mathrm{U} / \mathrm{mg}$, and $0.27 \times 10^{3}$ $\mathrm{U} / \mathrm{mg}$, respectively (Table 1 ). The dose response curve for Pool 1 demonstrates a clear reduction of TNF-like activity with increasing dilutions (Fig. 2). Eighty percent of the TNF-like activity remained after treatment of Pool I at $56^{\circ} \mathrm{C}$ for 


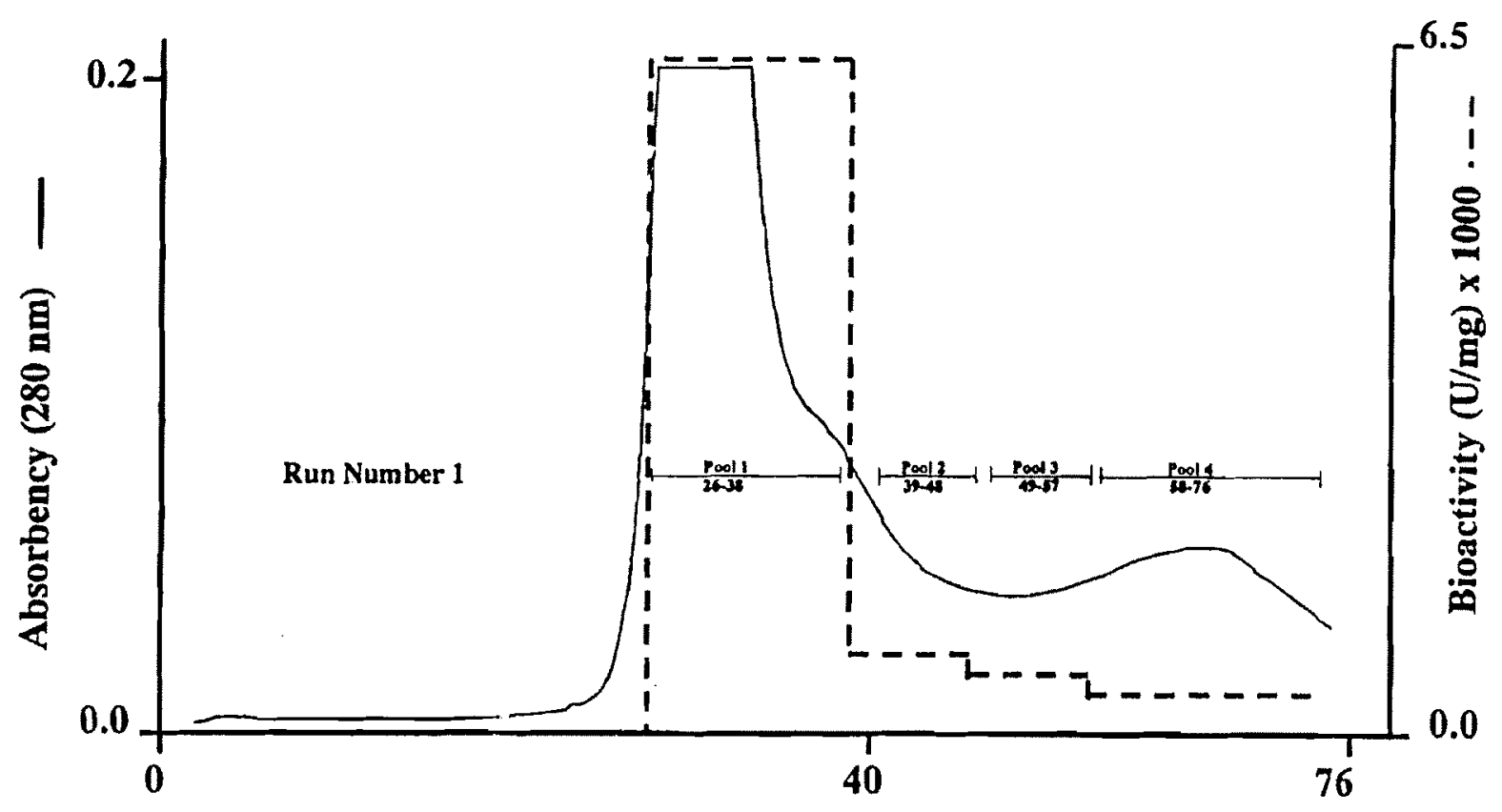

Fractions

Fig. 1. G-75 Sephadex gel-permeation chromatography. The column was equilibrated with buffer 2 . The pump flow rate was adjusted to $30 \mathrm{ml} / \mathrm{h}$. Fractions were measured by drops and were set at 38 drops per fraction which equals $1 \mathrm{ml}$. Using blue dextran (MW 2,000,000) and phenol red (MW 345), the column was calibrated. Blue dextran marks the $V_{0}$ (void volume) and phenol red marks the V, (total volume) of the column. Per run, $1 \mathrm{ml}$ of sample was loaded onto the column by gravity and fractionation was started immediately. Three runs with identical profiles were performed with $1 \mathrm{ml}$ of sample $\left(4.7 \times 10^{5} \mathrm{U}\right.$ of cytotoxic activity/ $\left.\mathrm{ml}\right)$. Four pools were collected in each run. The pools represent in order the void peak (pool 1: $>81 \mathrm{kDa}$ ); a shoulder of the void peak (pool 2: $70-55 \mathrm{kDa}$ ); a transition (pool 3: 40-35 kDa); and a small included peak (pool $4:<25 \mathrm{kDa}$ ). Pools $1-4$ were combined based on the protein profiles.

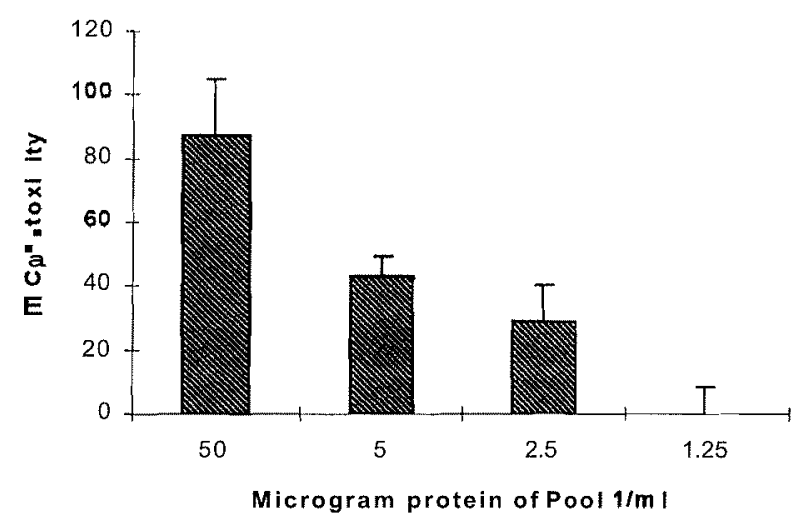

Fig. 2. Dose response of TNF-like factor (Pool 1) in the cytotoxicity assay.
30 min, suggesting heat stability of chicken TNF. like factor (data not shown) $[25,26]$. No cytotoxic activity remained after heating the sample to $95^{\circ} \mathrm{C}$ (data not shown). The biological activity of chicken TNF-like factor was not neutralised by the neutralising rabbit-anti-human TNF- $\alpha$ antiserum (data not shown).

\subsection{Macrophage stimulation by chicken TNF-like factor}

TNF has a potent activating effect on macrophages in mammals. Fig. $3 b$ shows that Pool 1 induced morphological changes in the chicken macrophage cells MQ-NCSU. The cellular granularity was increased and the number of cellular 

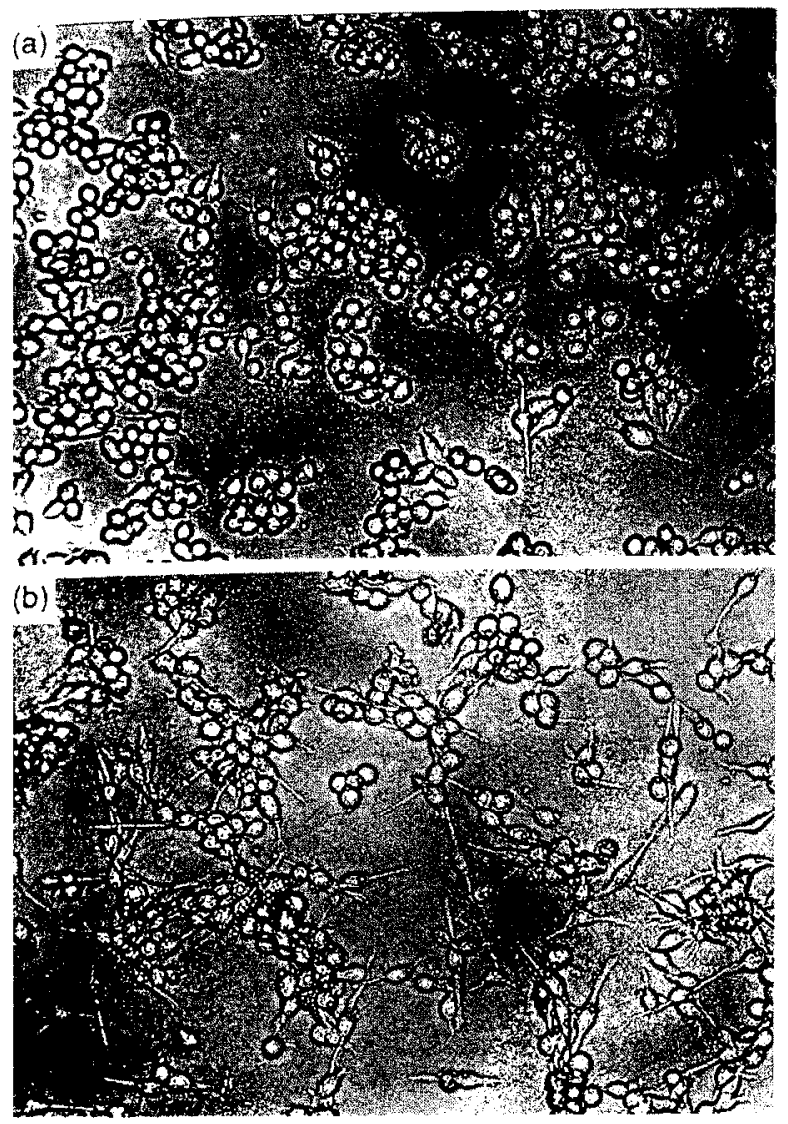

11. 3. Vorphological changes induced in MQ-NCSU cells. 1) Von-stimulated MQ-NCSU cells after $48 \mathrm{~h}$ of culture in :rinuth medium $(x+100)$. Less than $20 \%$ of the cells show celular extenstons and cytoplasmic granules. (b) MQ-NCSU ell. wher 48 h of stimulation with growth medium suplemented with L? $\mu \mathrm{g}$ of pool $11 \times 10^{6}$ cells $(\times 400)$. Over x", "it the cells show long cellular extensions and granules.

acensions was enhanced after stimulation with 'on) in comparison to the medium control T.thle 2. Fig. 3b). Furthermore. Pool 1 enhanced 1-exnression by MQ-NCSU cells by 2.38 fold ind induced NO production by HDIl cells r.ble 7. Fig. 4). No NO inducing activity amaned after heating the sample to $95^{\circ} \mathrm{C}$ (data wis hown)

Pool 2 had strong effects on NO induction and :nhanced la-expression 1.8 fold (Table 2). Pool 3 hinsed NO inducing activity but had no effect in la expression by MQ-NCSL cells (Table 2). $\therefore 1+$ had residual effects on macrophage acti-

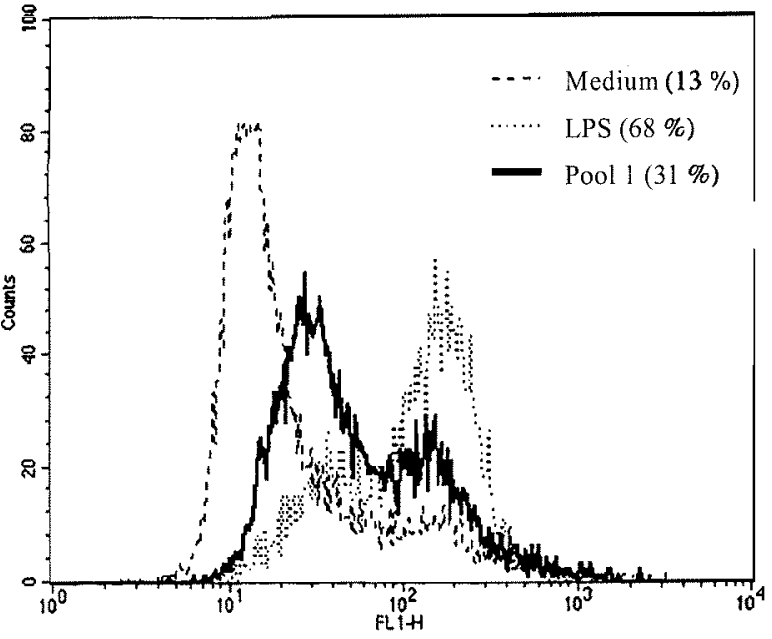

Fig. 4. Flow cytometric analysis of Ia-expression by MQNCSU cells after culturing with medium, LPS $(10 \mu \mathrm{g} / \mathrm{ml})$ or Pool $1(1: 200)$ for $48 \mathrm{~h}$. The percentage of cells positive for Ia-expression is presented in parenthesis.

vation, induced morphological changes, and enhanced Ia expression about 1.16 fold (Table 2).

These findings indicate that Pool I was positive for all the TNF-like biological activities we tested for. Pool 1 was used further to study synergistic effects of chicken TNF-like factor with IFN-y. In previous studies it was demonstrated that mammalian TNF had synergistic effects with IFN- $\gamma$ on NO induction [32]. Fig. 5 shows that chicken TNF-like factor had synergistic effects with chicken recombinant IFN-y on the induction of NO production by the chicken macrophage cell line HD11. While $32 \mathrm{U} / \mathrm{ml}$ of IFN-y alone only induced $18 \mu \mathrm{M}$ of NO, and chicken TNF-like factor at a dilution of 1:400 induced $24 \mu \mathrm{M}$ of NO or less. the combination of both cytokines enhanced NO production about three times.

\subsection{Western blot analysis of avian TNF-like factor}

Fig. 6 shows a Western blot analysis of Pool 1 and the FT fraction obtained from the ionexchange step. Lane 1 shows a $20 \mathrm{ng}$ application of rhTNF. The rabbit polyclonal anti-human TNF- $\alpha$ antiserum recognised a strong $17 \mathrm{kDa}$ protein band, possibly the TNF-monomer, and a 
Table 2

Macrophage activation by pools collected by GPC from LPS-stimulated MQ-NCSU cells (The results of two repeat experiment are presented.)

\begin{tabular}{llll}
\hline Pool $^{\mathrm{a}}$ & Induction of morphological changes & Time fold increase in la-expression & NO inducing factor $(\mathrm{U} / \mathrm{mg}$ \\
\hline 1 & $+++b$ & $2.38^{\mathrm{c}}$ & $6080 \pm 480^{\mathrm{d}},{ }^{1}$ \\
2 & - & 1.8 & $760.8 \pm 7.2^{2}$ \\
3 & - & 0 & $876.9 \pm 61.5^{2}$ \\
4 & ++ & 1.16 & $0 \pm 30.3^{3}$ \\
\hline
\end{tabular}

${ }^{\mathrm{a}}$ Pool 1. $>81 \mathrm{kDa}$ molecular weight proteins; pool 2, 70-55 kDa; pool 3,40-35 kDa; pool 4, <25 kDa.

$b+++.>90 \%$ of MQ-NCSU cells showed one or more cell-extensions and enhanced granularity after stimulation in compari son to non-stimulated control cell cultures;,$++ 80-50 \%$ of MQ-NCSU cells showed one or more cell-extensions;,$+ 50-20 \%$ o MQ-NCSU cells showed cell-extensions;,$-<20 \%$ of MQ-NCSU cells showed cell-extensions.

"MQ-NCSU cells were stimulated for $48 \mathrm{~h}$ with several fractions diluted 1:200 in medium. The cells were harvested and stainec for Ia-cell surface expression. The intensity of Ia expression was determined by flow cytometric analysis. $12 \pm 0.6 \%$ of unstimulatec MQ-NCSU cells expressed la.

${ }^{d}$ Average of two repeat experiments \pm standard deviation. Numbers with different superscript figures in one column are signifi cantly different $(\mathrm{P}<0.05)$.

weak band at $38 \mathrm{kDa}$. Lane 2 shows that the rabbit anti-human $\mathrm{TNF}$ antiserum recognised also a $17 \mathrm{kDa}$ protein in Pool 1. The antiserum detected additional proteins of $82 \mathrm{kDa}$ in Pool 1. Preimmune rabbit serum did not detect any protein bands in either of the tested samples (Pool 1 see lane 4 Fig. 6). Lane 3 shows that the polyclonal antiserum against rh TNF also recognised proteins of $82 \mathrm{kDa}$ in the $\mathrm{FT}$ fraction. No specific protein bands were detected by the polyclonal rabbit anti-rh TNF antiserum in Pools 2-4 (data not shown).

\section{Discussion}

This study demonstrated for the first time that chicken TNF-like factor has biological activitier homologous to mammalian TNF. Previous studies have indicated that chicken cells produce TNF following LPS or Eimeria stimulation $[17,19,20,33]$. The TNF was identified by a cytotoxicity assay or with cross-reacting polyclonal anti-mammalian TNF-antibodies $[17,19,21]$. However, these detection methods were not standardised for the chicken system and therefore $\mathrm{dc}$

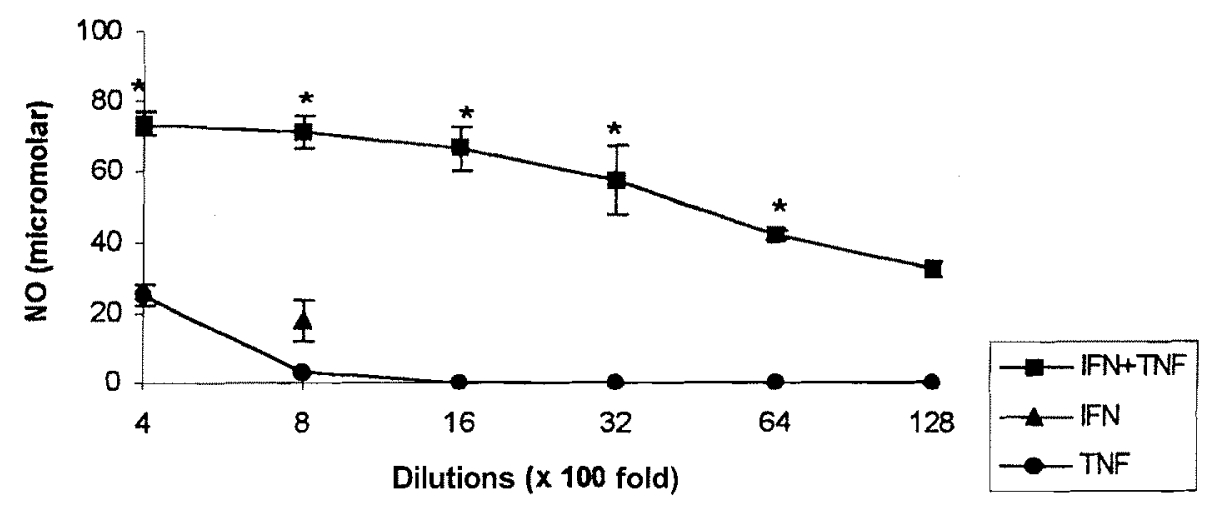

Fig. 5. Synergistic induction of NO production in HDI [ cells by serial dilutions of Pool 1 and chicken recombinant IFN-y (32 U/ $\mathrm{ml}$ ). The combined data of two repeat experiments are presented. The concentration of NO in non-stimulated or cultures stimulated with supernatant from CEFs infected with FPV was $<1 \mu \mathrm{M}$. TNF, chicken TNF-like factor: IFN, IFN-y. 'Significantly different than NO concentrations after stimulation with IFN-y or TNF-like factor alone $(P<0.05)$. 

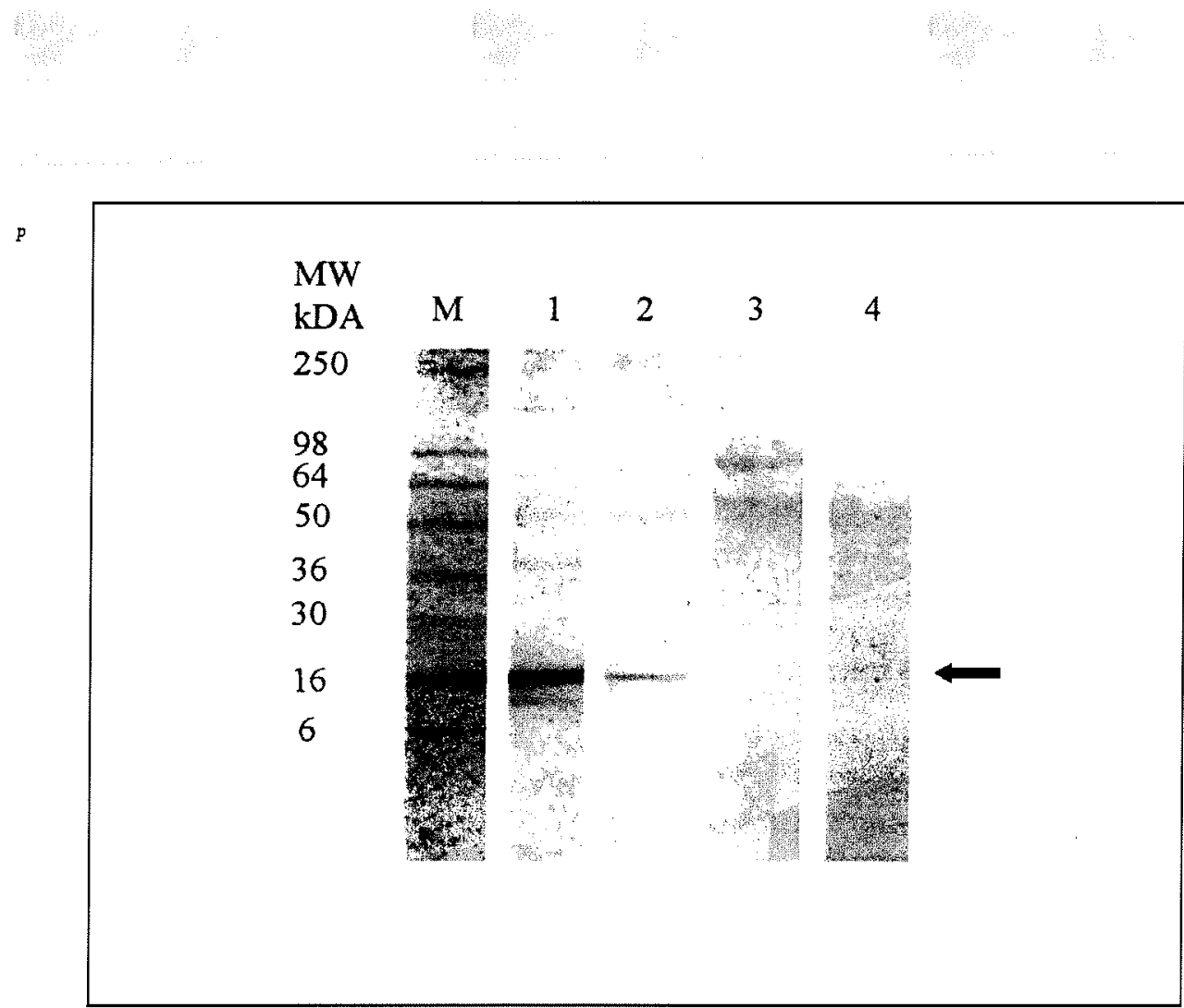

Fig. 6. Western blot of chicken TNF-like factor. SDS-PAGE-separated proteins were transblotted to a Imrnobilon-P transfer membrane then stained with rabbit polyclonal antibodies against recombinant human (rh) TNF- $\alpha$ (lanes 1-3), and developed with the prrouidase-system. Lane M: pre-stained molecular weight marker; lane 1: $20 \mathrm{ng}$ rh TNF: lane 2: $1 \mu \mathrm{g}$ of Pool 1; lane 3: $40 \mu \mathrm{g}$ of FT fraction. Lane 4:1 $1 \mathrm{~g}$ of Pool 1 stained with a $1: 500$ dilution of pre-immune rabbit serum. Arrow indicates the $17 \mathrm{kDa}$ protein pand of similar size to human TNF- $\alpha$ monomers.

not reflect specificity. The lack of specific monoslonal antibodies to identify chicken TNF makes $t$ necessary to characterise chicken TNF by more than one procedure.

Macrophages have been shown to release an mpressive panel of cytokines after stimulation such as IL-1, IL-1ra, IL-6, IL-8, IL-10, IL-12, TNF- $\alpha$, IFN-a, IFN- $\gamma$, MCP-1, MCP-3, MIF, M-CSF, G-CSF, GM-CSF, MIP-1, MIP-2, LIF, JSM, and TGF- $\beta$ [34]. They rapidly synthesise le novo mRNA and protein following activation. Yost of these cytokines show similar molecular ize and overlapping activities. To more specifially characterise chicken TNF, conditioned medum from LPS-stimulated macrophages was semisurified by chromatographical methods and ested for TNF-like activity in a variety of acivity assays.

By dialysing the supernatants from LPS-stimuated MQ-NCSU cells we separated molecules smaller than 12-14 $\mathrm{kDa}$ from our starting material. This procedure excluded chemokine monomers, which have a molecular weight of $8-10 \mathrm{kDa}$ [35] and may have overlapping functions with TNF [41] from our material. After two chromatography steps, most of the chicken TNF-like activity was recovered in the fractions containing proteins above $81 \mathrm{kDa}$ molecular weight. Some residual or additional activity was detected in other fractions, which may be due to other factors of different molecular weight having overlapping function with chicken TNF-like factor. Chicken TNF-like factor is likely to be a peptide multimer in its biologically most active form as shown for mammalian TNF [11]. Residual activity in pools containing proteins of lower molecular weight than $81 \mathrm{kDa}$ may be due to TNFmonomers or dimers. The Western blotting results support this speculation. After denaturation of the proteins from Pool 1, proteins of 
$17 \mathrm{kDa}$ were detected with polyclonal antihuman TNF antiserum. These proteins had a molecular weight homologous to the human TNF- $\alpha$ monomers. This finding coincides with that of Zhang et al. [19] who detected a $17 \mathrm{kDa}$ band in culture supernatant of blood leukocytederived macrophages stimulated with Eimeria sporozoites by using a polyclonal anti-human TNF-a serum. We also detected a weak band of proteins of $82 \mathrm{kDa}$ in Pool 1 and the FT fraction, cross-reacting with the polyclonal rabbit anti-human TNF- $\alpha$ antiserum. These may be multimer complexes of TNF not dissociated by the denaturing process.

Polyclonal anti-human TNF-a antiserum did not neutralise the biological activity of chicken TNF-like factor in vitro. This result is not unexpected because homology between chicken and mammalian cytokines cloned so far is relatively low on the protein level [36]. For example, chicken type I IFN has less than $30 \%$ homology to mammalian IFN on the amino acid level [30]. Type II IFN has less than $36 \%$ homology on the amino acid level to manmalian type II IFN [37].

As demonstrated by the Western blotting procedures, anti-TNF-a serum detects denatured chicken TNF-like factor monomers of $17 \mathrm{kDa}$ possibly due to the recognition of linear epitopes of TNF. The lack of neutralisation of the TNFlike bioactivity by the polyclonal anti-human TNF-a antiserum indicated that the homology of mammalian and chicken TNF at the native protein level may be very low. This may be a reason why attempts to clone chicken TNF on the basis of known mammalian TNF cDNA sequences failed.

Other studies indicated that polyclonal antihuman TNF-a antiserum neutralised chicken TNF-like activity partially in certain chicken strains in vivo [19]. Why anti-human TNF-a antiserum neutralised chicken TNF-like activity partially in vivo but not in vitro is not known.

To distinguish TNF-activity from biological activities of other cytokine in the fractionated supernatants of LPS-stimulated macrophages. we chose to test for a variety of biological functions characteristic of mammalian TNF. TNF is a very potent immunomodulator and stimulator of macrophage function. Major activities incluc the enhancement of the expression of MHC ger products and adhesion molecules [38]. Witse and Schook [39] showed a feedback control c monocgtic differentiation by TNF. TNF als induced chemotactic migration in human mond cytes at very low concentrations [40]. This stud demonstrated that chicken TNF is a macrophag stimulator. Pool 1 up-regulated $\mathrm{MHC}$ class $1 \mathrm{c} \mathrm{ex}$ pression 2.38 fold and induced morphologic: changes of macrophages. Pool 4 also showe some activity on the induction of morphologica changes. The effect of Pool 4 might be due to other factors than TNF or to monomers of TNI having some residual activity on macrophage ac tivation.

NO production is also an indication fo macrophage activation. The highest NO-inducing effect was shown after stimulation of HDI I cell with Pool 1. Some activity was also detected if Pools 2 and 3 . It is possible that our separation protocol isolated different $\mathrm{NO}$-inducing factors in Pools 2 and 3 that have not been characterised yet.

Chicken TNF synergised with IFN-y in the induction of NO production by macrophages. Similar observations were made in in vitro models with mammalian cells [41]. It was noted that IFN increased NO production and enhanced the cytotoxic effect of TNF on tumour cells $[42,43]$.

Similar to TNF, IL-1 is also produced by activated mononuclear phagocytes. It has several overlapping functions with TNF. The biologically active forms of IL-1 are monomers of approximately $17 \mathrm{kDa}$ [44]. By fractionating the supernatant of LPS-stimulated MQ-NCSU cells, we were able to exclude the possibility that we purified IL-1 instead of TNF, because the major activity was recovered in Pool 1 that contained proteins above $81 \mathrm{kDa}$ molecular weight. Although IL-1 shares extensive similarities with TNF-actions such as inflammatory and pro-coagulant properties, it does not increase MHC expression in cells [45]. In this study it was demonstrated that factors in Pool 1 up-regulated the expression of MHC class II on chicken macrophages. Based on these observations we 
soncluded that we did not collect chicken IL-1 in Pool 1."

For the first time it was shown that chicken TNF has several functions homologous to mamnalian TNF-a. Chicken TNF had cytotoxic activity for chicken fibroblast cells, induced NO production, and synergised with recombinant shicken IFN- $\gamma$. Chicken TNF enhanced Ia expression on MQ-NCSU macrophage cells and induced morphological changes in these cells. Chicken TNF may be a protein complex of above $81 \mathrm{kDa}$ in its active form. Based on these observations, we conclude that chicken macrophages indeed secrete a TNF-like factor, comparable in its activities with mammalian TNF-a.

\section{Acknowledgements}

The authors thank Steve Erickson, Gregory Mitcheltree, Blanca Martinez and Daniel Mickelson for their excellent technical assistance. This work was supported by the Deutsche Forschungsgemeinschaft (S.R.).

\section{References}

[1] Sidhu RS, Bollon AP. Tumor necrosis factor activities and cancer therapy - a perspective. Pharmacol Ther 1993;57(1):79-128.

[2] Goeddel DV, Aggarwal BB, Gray PW. Leung DW, Nedwin GE, Palladino MA, Patton JS, Pennica D, Shepard HM. Sugarman BJ, Wong GHW. Tumor necrosis factors: gene structure and biological activities. Cold Spring Harbor Symp Quant Biol L1 1986:51(1):597-609.

[3] Ito H, Shirai T, Yamamoto S, Akira M, Kawahara S, Todd CW, Wallace RB. Molecular cloning of the gene encoding rabbit tumor necrosis factor. DNA 1986:5(2):157-65.

14] Rimstad E, Reubel GH, Dean GA. Higgins J. Pedersen NC. Cloning, expression and characterization of biologically active feline tumour necrosis factor-r. Vet Immunol Immunopathol 1995;45(3-4):297-310.

[5] Seow H-F. Rothel JS, Pepin M. David M-J, Wood PR. Expression, biological activity and kinetics of production of recombinant ovine TNF-r. Vet Immunol Immunopathol 1995: 44(3-4):279-291.

[6] Kwon J, Chung IY, Benveniste EN. Cloning and sequence analysis of the rate tumor necrosis factorencoding gene. Gene 1993;32(2):227-36.

[7] Semon D. Kawashima E. Jongeneel CV. Shakhov AN.
Nedospasov SA. Nucleotide sequence of the murine TNF locus including the TNF-alpha (tumor necrosis factor alpha) and TNF-beta (lymphotoxin) genes. Nucleic Acids Res 1987;15(2);9083-4.

[8] Shakhov AN, Kuprash DV, Azizov MM, Jongeneel CV, Nedospasov SA. Structural analysis of the rabbit TNF locus, containing the genes encoding TNF- $\beta$ (lymphotoxin) and TNF-a (tumor necrosis factor). Gene 1990;95(2):215-21.

[9] Young AJ. Hay JB, Chan JY. Primary structure of ovine tumor necrosis factor alpha cDNA. Nucleic Acids Res 1990;18(22):6723.

[10] Zucker K. Lu P, Fuller L, Asthana D, Esquenazi V, Miller $J$. Cloning and expression of the CDNA for canine tumor necrosis factor-a in E. coli. Lymokine Cytokine Res 1994:13(3):191-6.

[II] Fiers W. Tumor necrosis factor. Characterization at the molecular, cellular, and in vivo level. FEBS Lett 1991;285(2): 199--212.

[12] Beutler B. The complex regulation and biology of TNF (cachectin). Crit Rev Oncog 1990;2(1):9-18.

[13] Grunfeld C, Palladino Jr MA. Tumor necrosis factor: immunologic, antitumor, metabolic, and cardiovascular activities. Adv Intern Med 1990;35:45-71.

[14] Vassalli $P$. The pathophysiology of tumor necrosis factors. Annu Rev Immunol 1992;10:411-52.

[15] Vilcek J, Lee TH. Tumor necrosis factor. New insights into the molecular mechanisms of its multiple actions. J Biol Chem 1991;266(12):7313-6,

[16] Kingston AE. Bergsteindottir K, Jessen KR, van der Meide PH, Colston MJ, Mirsky R. Schwann cells co-culn tured with stimulated $T$ cells and antigen express major histocompatibility complex (MHC) class II determinants without interferon-gamma pretreatment: synergistic effects of interferon-gamma and tumor necrosis factor on MHC class II induction. Eur J Immunol 1989;19(1):17783.

[17] Byrnes S, Eaton R. Kogut M. In vitro interleukin-l and tumor necrosis factor-alpha production by macrophages from chickens infected with either Eimeria maxima or Eimeriu tenella. Int J Parasitol 1993:23(5):639-45.

[18] Klasing KC. Avian leukocytic cytokines. Poult Sci 1994; $73: 1035-43$.

[19] Zhang S, Lillehoj HS. Ruff MD. In vivo role of tumor necrosis-like factor in Eimeria tenella infection. Avian Dis 1995;39(4):859-66.

[20] Zhang S, Lillehoj HS. Ruff MD. Chicken tumor necrosis-like factor. I. In vitro production by rnacrophages stimulated with Eimeria tenella or bacterial lipopolysaccharide. Poult Sci 1995;74(8):130410.

[21] Wride MA. Sanders EJ. Expression of tumor necrosis factor-r (TNF- $x$ )-cross-reactive proteins during early chick embryo development. Dev Dyn 1993:198(3):22539.

[22] Qureshi MA, Miller L. Lillehoj HS, Ficken MD. Establishment and characterization of a chicken mono- 
nuclear cell line. Vet Immunol Immunopath 1990:26(3): 237-50.

[23] Ogura H, Fujiwara T. Establishment and characterization of a virus-free chicken cell line. Acta Med Okayama 1987;41(3):141-3.

[24] Baarsch MJ, Wannemuehler M, Molitor TW, Murtaugh MP. Detection of tumor necrosis factor-alpha from porcine alveolar macrophages using L929 fibroblast bioassay. J Immunol Methods 1991;140(1):15-22.

[25] Männel DN, Moore RN, Mergenhagen SE. Macrophages as source of tumoricidal activity (tumor-necrotizing factor). Infect Immun 1980;30(2):523-30.

[26] Koyama Y, Hayashi T, Fujii N, Yoshida T. Recombinant mouse tumor necrosis factor expressed in mammalian cells: effect of glycosylation on cytotoxic activity. Biochim Biophys Acta 1992;1132(2):188-94.

[27] Pertile TL, Sharma JM, Walser MM, Reovirus infection in chickens primes splenic adherent macrophages to produce nitric oxide in response to $\mathrm{T}$ cell-produced factors. Cell Immunol 1995;164(2):207-16.

[28] Green LC, Wagner DA, Glogowski J, Skipper PL, Wishnok JS, Tannenbaum SR. Analysis of nitrate, nitrite, and $\left[\mathbb{N}^{15}\right]$ nitrate in biological fluids. Anal Biochem 1982;126(1):131-8.

[29] Rautenschlein S, Sharma JM, Winslow BJ, McMillen J, Junker D, Cochran M. Embryo vaccination of turkeys against Newcastle disease infection with recombinant fowlpox virus constructs containing interferons as adjuvants. Vaccine (in press) 1999

[30] Sekellick MJ, Marcus PI. Induction of high titer chicken interferon. Methods Enzymol 1986;119:115-25.

[31] Ewert DL, Shepherd Munchus M, Chen C-LH, Cooper $\mathrm{MD}$. Analysis of structural properties and cellular distribution of avian Ia antigen by using monoclonal antibody to monomorphic determinants. J Immunol 1984; 132(5):2524-30.

[32] Baskin H, Ellermann-Eriksen S, Lovmand J, Mogensen $\mathrm{SC}$. Herpes simplex virus type 2 synergizes with interferon-y in the induction of nitric oxide production in mouse macrophages through autocrine secretion of tumour necrosis factor-a. J Gen Virol 1997:78:195-203.

[33] Qureshi MA. Petitte JN, Laster SM, Dietert RR. Avian macrophages: contribution to cellular microenvironment and changes in effector functions following activation Poult Sci 1993;72(7):1280-4.

[34] Cavaillon JM. Cytokines and macrophages. Biomed Pharmacother 1994;48(40):445-53.

[35] Durum SK. Oppenheim JJ. Proinflammatory cytokines and immunity. In: Paul WE, editor. Fundamental immunology. New York: Raven Press, 1993. p. 801-35.

[36] Rautenschlein S, Sharma JM. Cytokines. In: Pastoret PP, Griebel P, Bazin H, Govaerts A, editors. Handbook of vertebrate immunology. London: Academic Press, 1988. p. 95-8.

[37] Digby MR, Lowenthal JW. Cloning and expression of the chicken interferon-y gene. J Interferon Cytokine Res 1995;15(11):933-8.

[38] Sherry B, Cerami A. Cachectin/tumor necrosis factor exerts endocrine, paracrime, and autocrine control on inflammatory responses. J Cell Biol 1988;107(4):1269-77.

[39] Witsell AL. Schook LB. Tumor necrosis factor $a$ is an autocrine growth regulatory during macrophage differentiation. Proc Natl Acad Sci USA 1992;89(10):4754-8.

[40] Ming WJ, Bersani L, Mantovani A. Tumor necrosis factor is chemotactic for monocytes and polymorphonuclear leukocytes. J Immunol 1987;138(5):1469-74.

[41] Ogura T, Esumi H. Nitric oxide synthase expression in human neuroblastoma cell line induced by cytokines. NeuroReport 1996;7(4):853-6.

[42] Williamson BD. Carswell EA, Rubin BY, Prendergasl JS, Old LJ. Human tumor necrosis factor produced by human B-cell lines: synergistic cytotoxic interaction with human interferon. Proc Natl Acad Sci USA 1983;80(17):5397-401.

[43] Bregman MD, Meyskens Jr FL. Human, recombinant alpha- and gamma-interferons enhance the cytotoxic properties of tumor necrosis factor on human melanoma. J Biol Response Mod 1988;7(4):384-9.

[44] Kronheim SR, March CJ, Erb SK, Conlon PJ, Mochizuki DY, Hopp TP. Human interleukin 1. Purification to homogeneity. J Exp Med 1985;161(3): 490-502.

[45] Cannon JG, Dinarello CA. Increased plasma interleukinI activity in women after ovulation. Science $1985 ; 227(4691): 1247-9$. 